\title{
Hydrogen evolution catalyzed by electrodeposited nanoparticles at the liquid/liquid interface $\dagger$
}

\author{
Joonas J. Nieminen, ${ }^{a b}$ Imren Hatay, ${ }^{a}$ PeiYu Ge, ${ }^{a}$ Manuel A. Méndez, ${ }^{a}$ Lasse Murtomäki ${ }^{b}$ \\ and Hubert H. Girault $* a$
}

Received 1st February 2011, Accepted 8th March 2011

DOI: $10.1039 / \mathrm{clcc10637f}$

Aqueous protons reduction by decamethylferrocene in 1,2-dichloroethane can be catalyzed efficiently by platinum and palladium nanoparticles electrogenerated in situ at the liquid-liquid interface.

Electrocatalytic reactions at the interface between two immiscible electrolyte solutions (ITIES), ${ }^{1}$ offer new opportunities for energy research such as hydrogen evolution, ${ }^{2}$ oxygen reduction ${ }^{1,3-8}$ or carbon dioxide reduction. These reactions can be driven by the interfacial potential difference, called Galvani potential difference, which can either be controlled potentiostatically using a four-electrode potentiostat or chemically by a judicious choice of supporting electrolytes in excess. For example, it has been shown that oxygen and proton could be reduced to hydrogen peroxide and hydrogen by the strong electron donor decamethylferrocene (DMFc) at the water/1,2-dichloroethane (DCE) interface under aerobic and anaerobic conditions, respectively. ${ }^{2,3}$ In the case of oxygen reduction, the catalytic effect of in situ generated interfacial $\mathrm{Pt}$ nanoparticles ${ }^{6}$ and that of different metalated ${ }^{4,5,8,9}$ and freebase porphyrins ${ }^{7,10}$ have also been demonstrated, showing that both adsorbed $\mathrm{Pt}$ particles and porphyrins can act as oxygen binding sites.

In the present communication, we present the catalytic properties of noble metal nanoparticles towards hydrogen evolution at ITIES. Both $\mathrm{Pt}$ and $\mathrm{Pd}$ nanoparticles are generated in situ at the water/DCE interface by the reduction of the respective metallic precursors $\mathrm{PtCl}_{4}{ }^{2-}$ and $\mathrm{PdCl}_{4}{ }^{2-}$ added to the aqueous phase, using lipophilic DMFc as the reducing agent. DMFc acts then as an electron donor agent both for the reduction of the aqueous metallic salts and that of the aqueous protons.

When the Galvani potential difference at the water/DCE interface is controlled externally using the electrochemical cell

${ }^{a}$ Laboratoire d'Electrochimie Phyique et Analytiqu, Station 6,

Ecole Polytechnique Fédédrale de Lausann, Lausanne, Switzerland.

E-mail: Hubert.Girault@epfl.ch; Fax: +41693 3667;

Tel: +416933145

${ }^{b}$ Aalto University, Department of Chemistry, PO Box 16100 ,

00076 Aalto, Finland.E-mail: lasse.murtomaki@ttk.fi;

Fax: + 3589470 22575; Tel: + 358947022575

$\dagger$ Electronic supplementary information (ESI) available: The video of

Hydrogen evolution. See DOI: 10.1039/clcc10637f

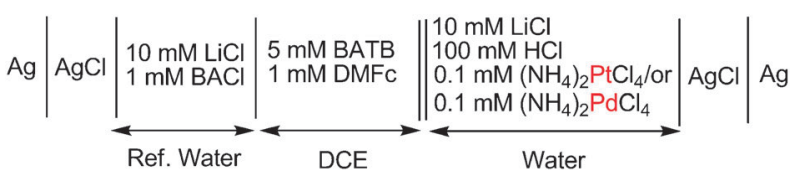

Scheme 1 Electrochemical cell composition, the double bar indicated the liquid-liquid interface where hydrogen evolution occurs.

shown in Scheme 1, cyclic voltammograms (CV) can be recorded as illustrated in Fig. 1. As indicated by the dashed line, a potential window ranging from -0.2 to $0.3 \mathrm{~V}$ is obtained when using $5 \mathrm{mM}$ BATB (bis(triphenylphosphoranylidene) ammoniumtetrakis-(pentafluorophenyl)borate) in DCE and $10 \mathrm{mM} \mathrm{LiCl}+100 \mathrm{mM} \mathrm{HCl}$ in water as supporting electrolytes. The positive and negative edges of this potential window are limited by the transfer of $\mathrm{H}^{+}$and $\mathrm{Cl}^{-}$from water to DCE, respectivelył. Indeed $\mathrm{BA}^{+}$and $\mathrm{TB}^{-}$are very lipophilic ions, their transfer cannot be observed within this potential window. ${ }^{11}$

As reported previously, ${ }^{2}$ after addition of $1 \mathrm{mM}$ DMFc to the DCE phase under anaerobic conditions, an irreversible current increase at positive potentials is observed (full line in Fig. 1). This behaviour can be related to a proton transfer reaction assisted by DMFc in DCE forming the metallocene hydride DMFc- $\mathrm{H}^{+}$. This step is followed by chemical reactions in the organic phase resulting in the evolution of hydrogen and the formation of decamethylferrocenium $\mathrm{DMFc}^{+}$. The presence of either $\mathrm{PtCl}_{4}{ }^{2-}$ or $\mathrm{PdCl}_{4}{ }^{2-}$ in the aqueous phase in the absence of DMFc does not give rise to any voltammetric response as compared to the blank CV (data not shown here). In the presence of both DMFc in DCE and the metallic precursor anion $\left(\mathrm{PtCl}_{4}{ }^{2-}\right.$ or $\left.\mathrm{PdCl}_{4}{ }^{2-}\right)$ in water, a very large current increase is observed as shown respectively by the dotted and long dashed lines in Fig. 1. In this case, the observed current increase can be attributed to the interfacial reduction of the $\mathrm{PtCl}_{4}{ }^{2-}$ or $\mathrm{PdCl}_{4}{ }^{2-}$ by $\mathrm{DMFc}$ leading to the formation of $\mathrm{Pt}$ and $\mathrm{Pd}$ nanoparticles at the liquid/liquid interface. ${ }^{12-14}$ Indeed, the present data corroborate the work of Kontturi et al. who studied the nucleation and growth of $\mathrm{Pd}$ nanoparticles at polarized liquid-liquid interfaces. $^{15-17}$

Considering that the standard redox potentials for the formation of $\mathrm{Pt}$ and $\mathrm{Pd}$ in the aqueous phase with respect to 


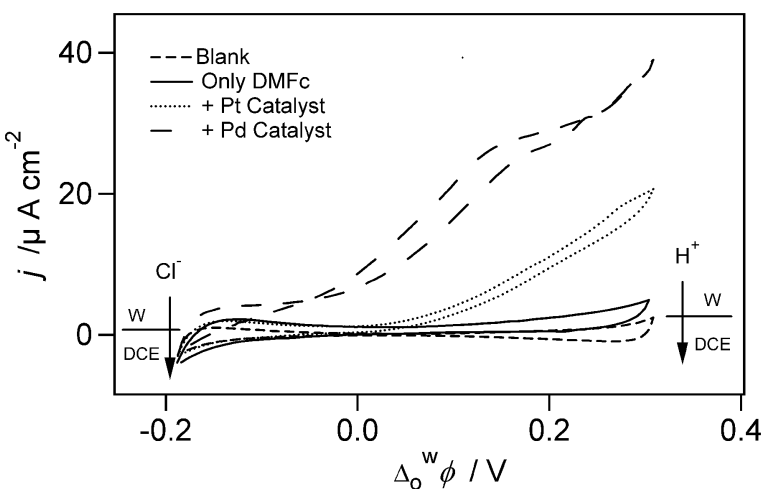

Fig. 1 Cyclic voltammograms obtained with the electrochemical cell shown in Scheme 1 in the presence of only DMFc (full line) in DCE and in the presence of both DMFc in DCE and $\mathrm{PtCl}_{4}{ }^{2-}$ or $\mathrm{PdCl}_{4}{ }^{2-}$ in the water phase. Scan rate $0.05 \mathrm{~V} \mathrm{~s}^{-1}$. The second scan is compared. All experiments are carried out under anaerobic conditions.

the standard hydrogen electrode $(\mathrm{SHE})$ are $\left[E_{\mathrm{PdCl}^{--} / \mathrm{Pd}}^{\mathrm{Pd}^{-}}\right]_{\mathrm{SHE}}^{\mathrm{W}}=$ $0.758 \mathrm{~V}$ and $\left[E_{\mathrm{PdCl}_{-}^{2-} / \mathrm{Pd}}^{\mathrm{Pd}^{-}}\right]_{\mathrm{SHE}}^{\mathrm{W}}=0.62 \mathrm{~V}$, respectively, the reduction of the metallic precursors by the organic electron donors is exergonic throughout the potential window, and the formation of $\mathrm{Pt}$ nanoparticles is thermodynamically more favorable than that of Pd. Indeed, the Gibbs energy for the salt reduction is

$$
\left.\Delta G_{R} / 2 F=\left[E_{\mathrm{DMFc}^{+} / \mathrm{DMFc}}^{\mathrm{D}_{\mathrm{SHE}}^{-}}\right]_{\mathrm{M}^{2+} / \mathrm{M}}^{\mathrm{o}}\right]_{\mathrm{SHE}}^{\mathrm{w}}-\Delta_{\mathrm{O}}^{\mathrm{w}} \phi
$$

where $\Delta_{\mathrm{o}}^{\mathrm{w}} \phi$ is the Galvani potential difference between the two phases, and the salt reduction can occur apart at very negative applied potentials as the standard redox potential for the electron donor in the organic phase is $\left[E_{\mathrm{DMFc}^{+} / \mathrm{DMFc}}^{\boldsymbol{D}^{-}}\right]_{\mathrm{SHE}}^{\mathrm{O}}=0.04 \mathrm{~V}$.

However, it has been reported by Dryfe et al. that Pd reduction occurs at a lower overpotential than $\mathrm{Pt}$ and this can also be observed in Fig. 1. The difference in the reduction kinetics of Pt and Pd salts has been explained by the difference in surface energies in the absence of the stabilizing effect of a solid substrate. Indeed, the surface energy plays an important role for controlling the nucleation rate at the liquid/liquid interface. $^{13}$

Metallic and semi-conducting nanoparticles have the property to adsorb at liquid-liquid interfaces as recently discussed by Flatté et al. ${ }^{18}$ and a key aspect of the present work is to show that these nanoparticles generated in situ at the liquidliquid interface have catalytic properties.

The catalytic effect of electrogenerated $\mathrm{Pt}$ and $\mathrm{Pd}$ particles on hydrogen evolution reaction (HER) by DMFc at the water/ DCE interface has been investigated by carrying out biphasic reactions and analyzing the head space by gas chromatography. Two phase reactions are carried out using a chemical control of the potential difference between the two phases by dissolving $5 \mathrm{mM} \mathrm{LiTB}+100 \mathrm{mM} \mathrm{HCl}+0.1 \mathrm{mM}\left(\mathrm{NH}_{4}\right)_{2} \mathrm{PtCl}_{4}$ or $\left(\mathrm{NH}_{4}\right)_{2} \mathrm{PdCl}_{4}$ in water and $5 \mathrm{mM} \mathrm{BATB}+5 \mathrm{mM} \mathrm{DMFc}$ in DCE. By this choice of electrolytes, the interface is polarized positively, approximately to $0.55 \mathrm{~V}$ as calculated considering the standard ion transfer potential of the different species. ${ }^{3}$ The reactions were carried out by mixing $2 \mathrm{ml}$ of aqueous and organic phases in a small glass flask and stirring for different time scales under anaerobic conditions. $1 \mathrm{ml}$ of the gas headspace above the two liquid phases was withdrawn by a syringe

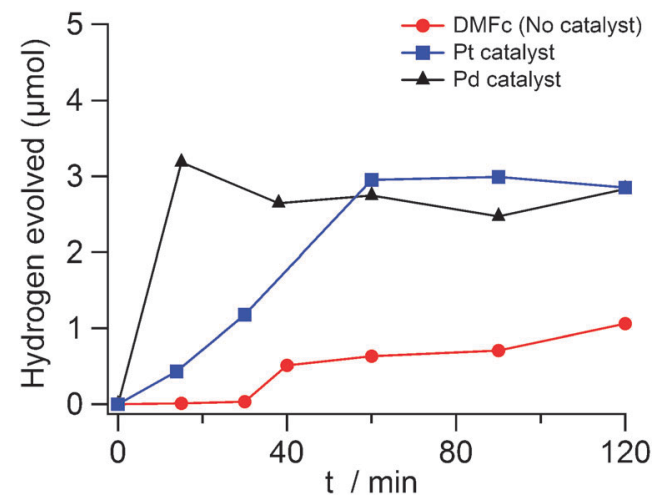

Fig. 2 The evolution of hydrogen as a function of time (min).

and injected in a GC for analysis to monitor the production of $\mathrm{H}_{2}$ presented in Fig. 2. In the absence of any metallic salt in the aqueous phase, the hydrogen formed is about $0.6 \mu \mathrm{mol}$, rising slowly during one hour. Using $0.1 \mathrm{mM}\left(\mathrm{NH}_{4}\right)_{2} \mathrm{PtCl}_{4}$ or $\left(\mathrm{NH}_{4}\right)_{2} \mathrm{PdCl}_{4}$ in water and $5 \mathrm{mM}$ DMFc in DCE, the hydrogen production reached about $3 \mu \mathrm{mol}$. It can be clearly observed that the HER proceeds faster in the presence of Pd nanoparticles compared to $\mathrm{Pt}$. This is likely due to the difference of nucleation rates discussed above, and as a result the interface becomes functionalised by metallic nanoparticles much faster with Pd. Hydrogen measured in the headspace after biphasic reactions carried out under stirring conditions should be in equilibrium with the two phases. The Henry's constant for water being $7.8 \times 10^{-4} \mathrm{M} \mathrm{atm}^{-1}$, and considering that the solubility of $\mathrm{H}_{2}$ in water $\left(7.5 \mathrm{mmol} \mathrm{l}^{-1}\right)$ is higher than in DCE $\left(2.2 \mathrm{mmol} \mathrm{l}^{-1}\right)$ at $1 \mathrm{~atm},{ }^{19}$ we can estimate that only about 0.11 micromoles of $\mathrm{H}_{2}$ remain dissolved in both liquid phases.

Hydrogen evolution was also monitored using a video camera (ESI $\dagger$ ) and a video snapshot of the interfacial $\mathrm{H}_{2}$ bubble formation is shown in Fig. 3. In the present case, a drop of $60 \mu \mathrm{l}$ of $50 \mathrm{mM} \mathrm{DMFc}$ and $5 \mathrm{mM}$ BATB were placed in a $0.1 \mathrm{mM}\left(\mathrm{NH}_{4}\right)_{2} \mathrm{PtCl}_{4}+5 \mathrm{mM} \mathrm{LiTB}+0.1 \mathrm{M} \mathrm{HCl}$ aqueous solution. After 15 minutes, the continuous production of hydrogen gas bubbles and color change from yellow to the green signifying the oxidation of $\mathrm{DMFc}$ to $\mathrm{DMFc}^{+}$can be observed under anaerobic and static conditions. In the absence of metallic precursors, the rate of bubble formation is much slower. Fig. 3 also illustrates the HER process at ITIES. It is important to stress the role of the interfacial polarisation controlled by the distribution of the supporting electrolytes in these biphasic reactions. Indeed, at zero Galvani potential difference, HER is endergonic if the proton reduction occurs

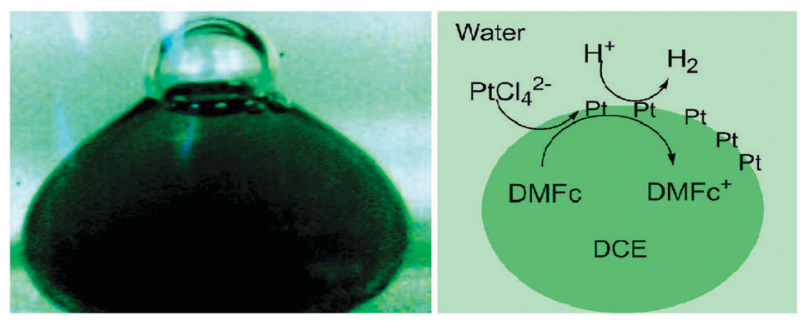

Fig. 3 Photograph and mechanism of the hydrogen evolution reaction by DMFc in the presence of in situ electrodeposited Pt catalyst. 
on the aqueous phase of the interface and DMFc oxidation in the organic side. For the reaction to proceed, the interface must be polarized as the driving force for the reaction is:

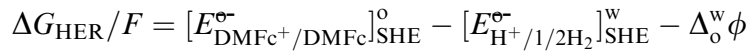

$\Delta G_{\mathrm{HER}}$ denotes the standard Gibbs energy for HER, $\left[E_{\mathrm{DMFc}^{-} / \mathrm{DMFc}}^{\mathrm{O}^{-}}\right]_{\mathrm{SHE}}^{\mathrm{O}}$ and $\left[E_{\mathrm{H}^{+} / 1 / 2 \mathrm{H}_{2}}^{\mathrm{O}^{-}}\right]_{\mathrm{SHE}}^{\mathrm{W}}$ represent the standard redox potentials of the $\mathrm{DMFc}^{+} / \mathrm{DMFc}$ and $\mathrm{H}^{+} / \mathrm{H}_{2}$ couples in the organic and in the water phase with respect to SHE, respectively. ${ }^{20}$ Indeed, no hydrogen has been detected by using ferrocene instead of DMFc which is less easily oxidized than DMFc and the HER remains endergonic $\left(\left[E_{\mathrm{Fe}^{+}}^{0^{-}} / \mathrm{Fe}\right]_{\mathrm{SHE}}^{\mathrm{O}}=0.64 \mathrm{~V}\right)$.

Of course, HER can also occur on the organic side of the interface following a proton transfer reaction. In this case, the driving force is simply

$$
\Delta G_{\mathrm{HER}} / F=\left[E_{\mathrm{DMFc}^{+} / \mathrm{DMFc}}^{\mathrm{D}^{-}}\right]_{\mathrm{SHE}}^{\mathrm{o}}-\left[E_{\mathrm{H}^{+} / 1 / 2 \mathrm{H}_{2}}^{\boldsymbol{O}^{-}}\right]_{\mathrm{SHE}}^{\mathrm{o}}
$$

with $\left[E_{\mathrm{H}^{+} / 1 / 2 \mathrm{H}_{2}}^{\mathrm{o}^{-}}\right]_{\mathrm{SHE}}^{\mathrm{o}}=0.55 \mathrm{~V}$. This value corresponds in fact to the Gibbs energy of proton transfer expressed in a voltage scale, and shows that proton reduction is easier to occur in the organic phase as it involves the disappearance of an ionic species. In this second scenario, the interfacial polarization is there to drive the proton transfer reaction.

HER can occur at liquid/liquid interfaces and the reaction can be catalyzed using in situ electrodeposited $\mathrm{Pt}$ and $\mathrm{Pd}$ nanoparticles. This opens new perspective for carrying out artificial photosynthesis at an organic liquid membrane.

This work was supported by EPFL, the Swiss National Science Foundation (FNRS 200020-116588) and the COST Action, D36/007/06.

\section{Notes and references}

$\ddagger$ An aqueous $50 \mathrm{mM}$ stock solution of $\left(\mathrm{NH}_{4}\right)_{2} \mathrm{PtCl}_{4}$ was prepared and aged for at least $3 \mathrm{~h}$ in order to reach equilibrium composition between the hydrolysis products of $\mathrm{PtCl}_{4}{ }^{2-}$, resulting in a mixture of $\mathrm{PtCl}_{4}{ }^{2-}$, [ $\left.\mathrm{PtCl}_{3}\left(\mathrm{H}_{2} \mathrm{O}\right)\right]^{-}$and $\mathrm{PtCl}_{2}\left(\mathrm{H}_{2} \mathrm{O}\right)_{2} .{ }^{14}$ The same procedure was applied for $\left(\mathrm{NH}_{4}\right)_{2} \mathrm{PdCl}_{4}$. BATB was prepared by metathesis of a $1: 1$ mixture of $\mathrm{BACl}$ with $\mathrm{LiTB}$ in a methanol/water mixture $(2: 1 \mathrm{v} / \mathrm{v})$ and subsequent recrystallization in acetone. The voltammetric measurements at the water/DCE interface were performed in a four-electrode configuration using PGSTAT 12 and $128 \mathrm{~N}$ potentiostats (Eco-Chemie, Netherlands). The area of the liquid/liquid interface was $1.53 \mathrm{~cm}^{2}$. The Galvani potential difference across the interface was estimated by assuming the formal ion transfer potential of tetraethylammonium cation $\left(\mathrm{TEA}^{+}\right)$to be $0.019 \mathrm{~V}^{21}$ The gas chromatograms were measured on a Perkin-Elmer gas chromatograph (Clarus 500) using a TCD detector and argon as the carrier gas.

1 M. A. Mendez, R. Partovi-Nia, I. Hatay, B. Su, P. Ge, A. Olaya, N. Younan, M. Hojeij and H. H. Girault, Phys. Chem. Chem. Phys., 2010, 12, 15163-15171.

2 I. Hatay, B. Su, F. Li, R. Partovi-Nia, H. Vrubel, X. Hu, M. Ersoz and H. H. Girault, Angew. Chem., Int. Ed., 2009, 48, 5139-5142.

3 B. Su, R. P. Nia, F. Li, M. Hojeij, M. Prudent, C. Corminboeuf, Z. Samec and H. H. Girault, Angew. Chem., Int. Ed., 2008, 47, 4675-4678.

4 B. Su, I. Hatay, A. n. Trojánek, Z. k. Samec, T. Khoury, C. P. Gros, J.-M. Barbe, A. Daina, P.-A. Carrupt and H. H. Girault, J. Am. Chem. Soc., 2010, 132, 2655-2662.

5 R. Partovi-Nia, B. Su, F. Li, C. P. Gros, J.-M. Barbe, Z. Samec and H. H. Girault, Chem.-Eur. J., 2009, 15, 2335-2340.

6 A. Trojánek, J. Langmaier and Z. Samec, Electrochem. Commun., $2006,8,475-481$.

7 A. Trojánek, J. Langmaier, B. Su, H. H. Girault and Z. Samec, Electrochem. Commun., 2009, 11, 1940-1943.

8 A. Trojánek, V. Marecek, H. Jänchenová and Z. Samec, Electrochem. Commun., 2007, 9, 2185-2190.

9 I. Hatay, B. Su, F. Li, M. A. Méndez, T. Khoury, C. P. Gros, J.-M. Barbe, M. Ersoz, Z. Samec and H. H. Girault, J. Am. Chem. Soc., 2009, 131, 13453-13459.

10 I. Hatay, B. Su, M. A. Méndez, C. m. Corminboeuf, T. Khoury, C. P. Gros, M. 1. Bourdillon, M. Meyer, J.-M. Barbe, M. Ersoz, S. Zális, Z. k. Samec and H. H. Girault, J. Am. Chem. Soc., 2010, 132, 13733-13741.

11 A. J. Olaya, M. A. Méndez, F. Cortes-Salazar and H. H. Girault, J. Electroanal. Chem., 2010, 644, 60-66.

12 M. Platt and R. A. W. Dryfe, Phys. Chem. Chem. Phys., 2005, 7, $1807-1814$.

13 M. Platt, R. A. W. Dryfe and E. P. L. Roberts, Electrochim. Acta, 2004, 49, 3937-3945.

14 A. Trojánek, J. Langmaier and Z. Samec, J. Electroanal. Chem., 2007, 599, 160-166.

15 R. Lahtinen, C. Johans, S. Hakkarainen, D. Coleman and K. Kontturi, Electrochem. Commun., 2002, 4, 479-482.

16 C. Johans, P. Liljeroth and K. Kontturi, Phys. Chem. Chem. Phys., 2002, 4, 1067-1071.

17 C. Johans, K. Kontturi and D. J. Schiffrin, J. Electroanal. Chem., 2002, 526, 29-35.

18 M. E. Flatté, A. A. Kornyshev and M. Urbakh, Faraday Discuss., 2009, 143, 109-115.

19 J. A. Waters, G. A. Mortimer and H. E. Clements, J. Chem. Eng. Data, 1970, 15, 174-176.

20 H. H. Girault, in Electroanalytical Chemistry, A series of Advances, ed. A. J. Bard and C. G. Zoski, CRC Press, Boca Raton, 2010, 1st. edn, vol. 23, ch. 1, pp. 1-104.

21 T. Wandlowski, V. Marecek and Z. Samec, Electrochim. Acta, 1990, 35, 1173-1175. 